\title{
ANALISIS KESULITAN BELAJAR MATEMATIKA SISWA KELAS V SD NEGERI TAMAN CIBODAS KECAMATAN PERIUK KOTA TANGERANG
}

\author{
${ }^{1}$ Aam Amaliyah, ${ }^{2}$ Candra Puspita Rini, ${ }^{3}$ Saktian Dwi Hartantri, ${ }^{4}$ Siska Yuliani \\ Program Studi Pendidikan Guru Sekolah Dasar \\ Fakultas Keguruan dan Ilmu Pendidikan \\ Universitas Muhammadiyah Tangerang \\ e-mail: ${ }^{1}$ aamamaliyah23@gmail.com, ${ }^{2}$ candrapuspitarini@gmail.com, ${ }^{3}$ saktiandwihartantri@gmail.com, \\ ${ }^{4}$ siskayuliani12@gmail.com
}

\begin{abstract}
Abstrak
Penelitian ini bertujuan untuk mengetahui kesulitan-kesulitan belajar yang dialami siswa dan mengetahui faktorfaktor yang mempengaruhi kesulitan belajar yang dialami siswa. Penelitian ini merupakan penelitian kualitatif deskriptif, subjek penelitian ini adalah siswa kelas 5 SD Negeri Taman Cibodas. Teknik pengumpulan data dilakukan dengan metode observasi, pemberian angket, dan tes matematika. Berdasarkan hasil penelitian didapat bahwa kesulitan belajar matematika yang dialami siswa tinggi dengan presentase $61 \%$. Kesulitan yang dialami siswa dalam belajar matematika yaitu kesulitan memahami penjelasan dan maksud soal, kesulitan memahami konsep, kesulitan dalam memahami simbol dan kesulitan dalam perhitungan. Faktor yang mempengaruhi kesulitan belajar adalah faktor internal diantaranya, kecerdasan rendah, sikap kurang memperhatikan pembelajaran, minat belajar rendah, dan motivasi belajar rendah. Faktor eksternal diantaranya kurangnya perhatian orang tua, suasana belajar di rumah kurang kondusif, kondisi lingkungan, pengaruh media massa, penyajian materi pembelajaran kurang menarik, metode pembelajaran kurang bervariasi, jarangnya media pembelajaran digunakan, dan saran pembelajaran belum lengkap.
\end{abstract}

Kata Kunci: kesulitan belajar, matematika, faktor-faktor penyebab.

\begin{abstract}
This research aims to determine the learning difficulties experienced by students and to determine the factors that affect learning difficulties experienced by students. This research is a descriptive qualitative research, the subject of this research is the 5th grade students of SD Negeri Taman Cibodas. The data collection technique was done by using the method of observation, giving questionnaires, and mathematics tests. Based on the results of the study, it was found that the difficulty in learning mathematics experienced by students was high with a percentage of $61 \%$. The difficulties experienced by students in learning mathematics are difficulty understanding the explanation and purpose of the problem, difficulty understanding concepts, difficulty understanding symbols and difficulty in calculations. Factors that affect learning difficulties are internal factors, including low intelligence, less attention to learning, low learning interest, and low learning motivation. External factors include the lack of parental attention, the learning atmosphere at home is less conducive, environmental conditions, the influence of mass media, the presentation of learning material is less attractive, less varied learning methods, rarely used learning media, and incomplete learning suggestions
\end{abstract}

Keywords: learning difficulties, math, causative factors. 


\section{PENDAHULUAN}

Mengajar merupakan suatu kegiatan yang memerlukan keterampilan profesional dan banyak hal yang harus dikerjakan oleh guru di dalam maupun di luar kelas yang melibatkan pengambilan berbagai keputusan. Di masa lampau, banyak dari keputusan-keputusan ini diambil hanya berdasarkan pemikiran ala kadarnya saja. Pendekatan seperti itu untuk masa sekarang tidak dapat lagi diterapkan. Menurut Undang-Undang No 20 Tahun 2003 tentang Sistem Pendidikan Nasional Pasal 1 ayat (6) berbunyi "Pendidik adalah tenaga kependidikan yang berkualifikasi sebagai guru, dosen, konselor, pamong belajar, widyaiswara, tutor, instruktur, fasilitator, dan sebutan lain yang sesuai dengan kekhususannya, serta berpartisipasi dalam menyelenggarakan pendidikan”. Dengan demikian, jelas bahwa guru memiliki tugas dan peran penting dalam kegiatan pembelajaran di kelas. Kadang guru memperlakukan siswanya kurang sesuai dengan kemampuan siswa. Perlakuan yang sama antara siswa satu dengan yang lain tanpa melihat potensi dan gaya belajar masing-masing akan berdampak kurang meratanya prestasi siswa dalam pembelajaran.

Dari pihak siswa, karakter ataupun potensi yang dibawa oleh tiap siswa tentunya berbeda satu dengan yang lain. Perbedaaan potensi membutuhkan penekanan yang berbeda untuk mencapai titik maksimal prestasi.. Hal ini dikarenakan, kesulitan belajar berakar pada aspekaspek psikologis terutama gangguan kepribadian dan penyesuaian diri. Sebagai masalah psikologis kesulitan belajar menuntut usaha pemecahan dengan pendekatan yang lebih bersifat psikologis pula. Bantuan yang diberikan tidak hanya bersifat instruksional pedagogis tetapi juga bantuan yang bersifat terapi. Siswa yang mengalami kesulitan belajar tidak hanya dibantu dalam memperoleh keterampilan belajar, tetapi dibantu dalam memahami dirinya, serta mengarahkanya agar terdapat perkembangan yang harmonis dan optimal.

Secara umum, kesulitan belajar yang dihadapi siswa bukan hanya pada mata pelajaran yang bersifat alamiah saja, akan tetapi lebih dari pada itu. Mata pelajaran yang bersifat hitungmenghitung, berhubungan dengan angka-angka dan rumus-rumus kerap kali mendatangkan kesulitan bagi siswa. Seperti pada mata pelajaran matematika. Kesulitan belajar matematika merupakan hal lazim dan hampir terjadi di seluruh jenjang sekolah dari SD hingga SMA. Matematika merupakan mata pelajaran yang tidak terlepas dari kehidupan sehari-hari. Kegiatan yang dilakukan oleh manusia selalu menghadirkan konsep matematika seperti menghitung, membagi, menjumlahkan, dan mengurangi. Belajar matematika mampu melatih seseorang untuk berpikir logis dan teliti. Peran pembelajaran matematika itu sendiri sangat besar bagi kehidupan manusia menjadikan matematika sebagai pelajaran yang jadikan syarat bagi 
kelulusan siswa untuk melanjutkan ke sekolah yang lebih tinggi. Namun, hampir dikalangan siswa khususnya di Sekolah Dasar, matematika dijadikan mata pelajaran yang paling sulit dan menakutkan.

Berdasarkan observasi yang peneliti lakukan dengan wali kelas V SD Negeri Taman Cibodas Kecamatan Periuk Kota Tangerang, banyak siswa yang mengalami kesulitan belajar pada mata pelajaran matematika. Hal tersebut dapat terlihat dari hasil belajar siswa yang hampir 85\% di bawah Kriteria Ketuntasan Mininal (KKM). Selain itu, kurangnya minat siswa dalam berhitung menjadi salah satu penyebab siswa kesulitan belajar matematika. Ini menjadi tugas penting bagi guru, karena selain menyampaikan materi pembelajaran, guru juga harus mampu meningkatkan minat belajar siswa pada mata pelajaran apapun. Hal lain yang menyebabkan siswa mengalami kesulitan belajar adalah media pembelajaran. Media pembelajaran merupakan salah satu cara untuk mempermudah dan membantu guru dalam menyampaikan materi pembelajaran secara kongkret. Dalam pelajaran matematika itu sendiri, media pembelajaran dapat dijadikan salah satu cara untuk meningkatkan stimulus siswa dalam belajar. Namun terkadang, masih banyak guru yang mengajarkan pembelajaran matematika dengan menggunakan media pembelajaran lama yaitu papan tulis.

Faktor paling penting siswa mengalami kesulitan belajar adalah faktor internal yang terdapat pada diri siswa itu sendiri. Faktor internal yang dimaksud adalah faktor fisiologis. Faktor fisiologis berkaitan dengan kurang berfungsinya otak, susunan syaraf atau pun bagianbagian tubuh yang lain. Guru harus menyadari bahwa hal yang paling penting berperan pada waktu belajar matematika adalah kesiapan otak siswa dalam menerima, memproses, menyimpan dan memunculkan kembali informasi yang sudah disimpan. Kondisi fisik yang berkaitan dengan kesehatan siswa juga sangat mempengaruhi proses belajar, jika anak sakit tentunya ia akan lemah dalam menerima pembelajaran matematika yang disampaikan oleh guru. Selain faktor internal, terdapat juga faktor eksternal yang menyebabkan siswa mengalami kesulitan belajar. Salah satu faktornya adalah berasal dari lingkungan, seperti lingkungan sekolah, lingkungan keluarga, maupun lingkungan sekitarnya.

Siswa berkesulitan belajar matematika bukan tidak mampu belajar, tetapi mengalami kesulitan tertentu yang menjadikannya tidak siap belajar. Matematika sering menjadi pelajaran yang paling ditakuti di sekolah. Lerner dalam Abdurrahman (2003) menyebutkan kesulitan belajar matematika disebut juga diskalkulia (dyscalculia). Kirk K \& Payne B (2012) menyebutkan "Dyscalculia is a difficulty with the concept of numbers". Siswa dengan gangguan diskalkulia disebabkan oleh ketidakmampuan mereka dalam membaca, imajinasi, 
mengintegrasikan pengetahuan dan pengalaman, terutama dalam memahami soal-soal cerita. Siswa diskalkulia tidak bisa mencerna sebuah fenomena yang masih abstrak. Biasanya sesuatu yang abstrak itu harus divisualisasikan atau dibuat kongkret, baru mereka bisa mencerna. Karakteristik siswa yang mengalami kesulitan belajar matematika adalah sebagai berikut; gangguan hubungan keruangan, abnormalitas persepsi visual, asosiasi visual-motor, persevasi, kesulitan mengenal dan memahami simbol, gangguan penghayatan tubuh, dan kesulitan dalam membaca dan bahasa (Mulyono, 2008, h.178).

Anak berkesulitan belajar matematika sering membuat kekeliruan atau kesalahan dalam belajar matematika, misalnya menyebutkan kesalahan atau kekeliruan anak berkesulitan belajar matematika yaitu kekeliruan dalam belajar berhitung, kekeliruan dalam belajar geometri, dan kekeliruan umum dalam menyelesaikan soal cerita. Siswa berkesulitan belajar matematika memiliki karakteristik atau ciri-ciri tertentu. Lerner (1984) menyebutkan bahwa beberapa karakteristik siswa berkesulitan dalam belajar matematika adalah sebagai berikut; 1) Gangguan Hubungan Keruangan, konsep hubungan keruangan seperti atas bawah, puncak dasar, jauh dekat, tinggi rendah, depan belakang, awal akhir umumnya telah dikuasai oleh anak sebelum masuk SD, namun bagi anak berkesulitan belajar matematika memahami konsep-konsep tersebut mengalami kesulitan; 2) Abnormalitas Persepsi Visual, siswa berkesulitan belajar matematika sering mengalami kesulitan untuk melihat berbagai obyek dalam hubungannya dengan kelompok; 3) Asosiasi Visual-Motor, siswa berkesulitan belajar matematika sering tidak dapat berhitung benda-benda secara berurutan, anak mungkin baru memegang benda yang kedua tetapi mengucapkan empat. Anak-anak semacam ini dapat memberikan kesan mereka hanya menghafal bilangan tanpa memahami maknanya; 4) Perseverasi, gangguan pada anak yang dimana perhatiannya melekat pada satu obyek dalam jangka waktu relatif lama dan hanya terkesan pada objek itu saja; 5) Kesulitan Mengenal dan Memahami Simbol, anak berkesulitan belajar matematika sering mengalami kesulitan dalam mengenal dan menggunakan simbol-simbol matematika seperti (+), (-), (X), (:), (=), (<), (>) dan sebagainya. Kesulitan semacam ini dapat disebabkan oleh adanya gangguan memori tetapi juga dapat disebabkan oleh adanya gangguan persepsi visual; 6) Gangguan Penghayatan Tubuh, anak berkesulitan belajar matematika juga sering menunjukkan adanya gangguan penghayatan tubuh (body image), misalnya jika disuruh menggambar tubuh secara keseluruhan, maka tidak ada yang tergambar secara utuh; 7) Kesulitan dalam Membaca dan Bahasa, anak berkesulitan belajar matematika akan mengalami kesulitan dalam memecahkan soal-soal yang berbentuk cerita (Mulyono, 2008, h. 172). 
Runtukahu \& Kandou (2014, h. 55-56) menyebutkan karakteristik anak berkesulitan belajar matematika yaitu: kesulitan memahami konsep hubungan spasial (keruangan), kesulitan dalam memahami konsep arah dan waktu, abnormalitas persepsi visual spasial, asosiasi visual-motor, kesulitan mengenal dan memahami simbol, persevasi, kesulitan dalam bahasa ujaran dan tulisan. Anak berkesulitan belajar matematika sering membuat kekeliruan atau kesalahan dalam belajar matematika (Runtukahu \& Kandou, 2014. h.252-259). Lebih lanjut Runtukahu \& Kandou menyebutkan kesalahan atau kekeliruan anak berkesulitan belajar matematika yaitu kekeliruan dalam belajar berhitung, kekeliruan dalam belajar geometri, dan kekeliruan umum dalam menyelesaikan soal cerita. Beberapa kesalahan umum yang dilakukan oleh siswa yang berkesulitan dalam belajar matematika menurut Lerner dalam Mulyono (2008 h.178) adalah kekurangan pemahaman tentang : simbol, nilai tempat, perhitungan, penggunaan proses yang keliru, dan tulisan yang tidak terbaca.

Selain itu, siswa berkesulitan belajar matematika dikarenakan pengelolaan kegiatan belajar yang tidak membangkitkan motivasi belajar siswa. Guru cenderung menggunakan metode pembelajaran yang membuat siswa jenuh seperti ceramah dan tugas-tugas yang kurang memotivasi siswa. Penelitian kesulitan belajar ini sangat penting dilakukan. Hal ini bertujuan untuk mengetahui faktor apa saja yang menjadi penyebab siswa mengalami kesulitan belajar matematika di sekolah dasar. Karena pada jenjang sekolah dasar, siswa sudah memiliki karakteristik yang berbeda-beda antara siswa satu dengan lainnya. Sehingga pada penelitian ini, dapat membantu untuk mengenal penyebab siswa sulit belajar yang disesuaikan pula dengan karakteristik mereka. Berdasarkan permasalahan yang telah diuraikan di atas, maka peneliti tertarik melakukan penelitian yang berjudul "Analisis Kesulitan Belajar Matematika Siswa pada Kelas V di SD Negeri Taman Cibodas Kecamatan Periuk Kota Tangerang”.

\section{METODE PENELITIAN}

Pendekatan yang digunakan dalam penelitian ini adalah pendekatan kualitatif, yang merupakan prosedur kerja untuk menghasilkan data deskriptif berupa kata-kata tertulis atau lisan dari orang-orang dan perilaku yang dapat diamati. Penelitian ini dilakukan di SD Negeri Taman Cibodas, yang berlokasi di Jalan Duta Raya Taman Cibodas, Kecamatan Periuk, Kabupaten Sanging Jaya, Kota Tangerang. Subjek penelitian merupakan sumber data yang dimintai informasinya sesuai dengan masalah yang diteliti. Dalam penelitian ini yang menjadi sumber data adalah 1 guru wali kelas V dan 31 siswa kelas V. Adapun fokus masalah dalam penelitian ini adalah kesulitan belajar matematika dan faktor-faktor kesulitan belajar 
matematika. Secara umum, siswa yang mengalami kesulitan belajar matematika dapat diidentifikasi melalui kesalahan atau kekeliruan siswa dalam mengerjakan soal matematika yang meliputi kesalahan membaca dan memahami maksud soal, kesalahan pemahaman konsep, kesalahan penggunaan rumus atau penggunaan notasi dan simbol, kesalahan ketrampilan proses, dan kesalahan karena kecerobohan. Siswa berkesulitan belajar matematika memiliki karakteristik atau ciri-ciri tertentu. Teknik pengumpulan data yang digunakan dalam penelitian ini adalah teknik observasi, tes dan angket.

Instrumen pengumpulan datanya adalah berupa pedoman observasi, tes uraian dan pedoman angket. Observasi digunakan untuk untuk melihat lebih dekat kegiatan pembelajaran yang dilakukan, mengamati sendiri serta mencatat perilaku dan kejadian yang sebenarnya. Tes digunakan sebagai instrumen pengumpul data berupa pertanyaan atau latihan yang digunakan untuk mengukur keterampilan pengetahuan, intelegensi, serta kemampuan yang dimiliki siswa. Angket digunakan untuk mencari informasi yang lengkap mengenai suatu masalah dan responden memberikan jawaban yang tidak sesuai dengan kenyataan dalam pengisian daftar pertanyaan. Teknik analisis data dalam penelitian ini mengacu pada model analisis dari Miles dan Huberman yaitu reduksi data, penyajian data dan verifikasi data (menarik kesimpulan), sedangkan untuk keabsahan data dilakukan dengan triangulasi teknik.

\section{HASIL DAN PEMBAHASAN}

Hasil penelitian diperoleh dengan cara analisis data yang mencakup penelitian angket kesulitan belajar siswa dan analisis hasil tes siswa. Responden dalam penelitian ini adalah siswa kelas V SD Negeri Taman Cibodas dengan jumlah responden sebanyak 31 siswa. Deskripsi data penelitian ini mencakup presentase hasil kesulitan belajar siswa dan persentase hasil tes siswa. Analisis hasil angket minat membaca mencakup dua faktor yang mempengaruhinya yaitu faktor intern yang berasal diri sendiri, dan faktor ekstern yang berasal dari keluarga, guru, maupun sekolah. Analisis hasil tes siswa mencakup karakteristik kesulitan belajar matematika.

Dari observasi yang dilakukan di kelas V, guru dan siswa memiliki komunikasi yang baik. Guru mampu menciptakan suasana sehingga terjadi interaksi positif antara guru dan murid. Interaksi ini terlihat ketika guru sedang menjelaskan materi. Guru memberikan kesempatan kepada siswa untuk bertanya. Selain itu, guru juga membahas beberapa soal secara bersama-sama, hal ini bertujuan agar siswa merasa dilibatkan saat proses pembelajaran dan 
siswa tidak pasif. Namun pada saat guru menjelaskan, terdapat beberapa siswa yang tidak fokus terhadap pembelajaran.

Untuk mengetahui letak kesulitan belajar matematika yang di alami siswa di kelas V maka dilakukan pengumpulan data dengan tes. Dari hasil tes, terdapat 6 murid yang mendapatkan nilai di atas KKM yaitu dengan presentase sebesar 19,35\%. Dan siswa yang masih berada di bawah KKM ada 25 siswa dengan prensentase 80,65\%. Tabel hasil tes matematika kelas V sebagai berikut :

Tabel 1. Persentase Jumlah Siswa Berdasarkan Kategori Kesulitan

\begin{tabular}{|c|c|c|c|}
\hline No & $\begin{array}{c}\text { Kategori } \\
\text { Kesulitan }\end{array}$ & $\begin{array}{c}\text { Jumlah } \\
\text { Siswa }\end{array}$ & Persentase \\
\hline 1 & Sangat Tinggi & 8 & $25,81 \%$ \\
\hline 2 & Tinggi & 9 & $29,03 \%$ \\
\hline 3 & Cukup & 5 & $16,13 \%$ \\
\hline 4 & Rendah & 3 & $9,68 \%$ \\
\hline 5 & Sangat Rendah & 6 & $19,35 \%$ \\
\hline
\end{tabular}

Berdasarkan tabel di atas, dapat dicermati bahwa tingkat kesulitan belajar matematika siswa kelas V dalam mengerjakan soal masih tinggi. Kesalahan tertinggi yang dilakukan siswa adalah kesalahan dalam keterampilan berhitung, yakni ketika siswa harus melakukan pengurangan simpan pinjam, kemudian pembagian dan perkalian. Kesulitan dalam keterampilan ini dapat terjadi karena beberapa kemungkinan, antara lain kurang telitinya siswa dalam melakukan perhitungan atau pemahaman siswa tentang konsep-konsep komputasional yang belum melekat pada siswa.

Data temuan dari hasil angket dengan siswa terlihat bahwa kesulitan belajar siswa disebabkan oleh faktor intern dan faktor ekstern. Faktor intern yang menjadi fokus dalam penelitian ini adalah minat dan motivasi siswa dalam mengikuti pembelajaran matematika. Berdasarkan ringkasan hasil temuan dari angket dengan siswa kelas V di SD Negeri Taman Cibodas dapat disimpulkan bahwa minat dan motivasi siswa yang rendah menjadi penyebab banyaknya siswa yang mengalami kesulitan belajar. Siswa yang berkesulitan belajar cenderung memiliki minat dan motivasi yang rendah dalam pembelajaran matematika, hal ini terlihat dari siswa yang tidak aktif pada saat pembelajaran di kelas, mereka cenderung tidak mau bertanya pada saat guru memberikan kesempatan untuk bertanya. Selain itu siswa malas mengerjakan latihan atau tugas yang diberikan oleh guru. Siswa yang berkesulitan juga sering ribut di kelas 
dan tidak memperhatikan penjelasan guru. Hal ini menunjukan minat dan motivasi siswa dalam pelajaran matematika kurang, sehingga mereka kurang tertarik dalam mengikutinya. Ketidaktertarikan ini bisa saja disebabkan karena adanya kesan bahwa matematika adalah pelajaran yang sulit.

Faktor eksternal yang menyebabkan kesulitan belajar berdasarkan hasil angket ialah lingkungan. Lingkungan sosial terlihat dari siswa yang mengalami hambatan dalam belajarnya kebanyakan berasal dari latar belakang lingkungan sosial yang kurang baik, seperti latar belakang orang tua dengan tingkat ekonomi yang rendah, ataupun kurang mendapat perhatian dari orang tua. Berdasarkan hasil angket faktor guru tidak mempengaruhi kesulitan belajar siswa. Guru harus memahami bahwa kemampuan setiap siswa berbeda-beda, serta tidak semua siswa menyenangi mata pelajaran matematika. Pada langkah-langkah pengerjaan soal matematika yang berbentuk uraian siswa bisa saja melakukan kesalahan-kesalahan. Dari kesalahan ini dapat dilihat jenis kesulitan yang dimiliki oleh siswa.

\section{SIMPULAN DAN SARAN}

Berdasarkan hasil penelitian dan pembahasan dapat disimpulkan bahwa kesulitan belajar matematika siswa kelas V di SD Negeri Taman Cibodas masih tinggi. Hal ini terlihat dari masih tingginya kesalahan-kesalahan yang dilakukan siswa dalam penyelesaian soal. Hanya 6 siswa yang mencapai nilai di atas KKM dengan persentase $19.35 \%$. Kesulitan yang dialami siswa dalam mengerjakan soal pada tes belajar matematika secara keseluruhan yaitu kesulitan atau lemah dalam perhitungan, kesulitan dalam memahami isi soal, kesulitan dalam mentransformasikan soal menjadi kalimat matematika dan kesulitan dalam mengingat rumusrumus matematika yang telah dipelajari sebelumnya. Faktor-faktor yang menyebabkan kesulitan belajar matematika siswa di kelas V meliputi, faktor internal dan faktor eksternal. Faktor internal meliputi minat dan movitasi siswa terhadap pembelajaran matematika. Sedangkan faktor eksternal meliputi lingkungan siswa baik lingkungan di rumah maupun di sekolah.

Saran yang dapat diberikan peneliti yaitu bagi guru perlu membangkitkan semangat dan motivasi belajar siswa terutama dalam pelajaran matematika. Guru perlu memberikan penjelasan yang lebih mendalam dengan menggunakan media pembelajaran untuk mempermudah dan memberi pemahaman konsep matematika. Untuk keterampilan berhitung guru menyampaikan dengan jelas bagaimana sistematika menghitung yang benar untuk menyelesaikan suatu soal, sedangkan untuk pemecahan masalah guru hendaknya dalam 
mengajarkan pemecahan masalah suatu persoalan kepada siswa disertai dengan langkahlangkah-langkah penuntun yang dapat memancing siswa memahami isi soal dan menghubungkan dengan konsep matematika. Bagi peneliti lain, sebaiknya pada penelitian selanjutnya diberikan remidiasi agar siswa semakin paham dengan letak kesalahan yang dilakukan dan dapat membantu siswa dalam mengatasi kesulitan belajar yang dialami siswa.

\section{DAFTAR PUSTAKA}

Abdurrahman, Mulyono. (2012). Anak Berkesulitan Belajar. Jakarta: Rineka Cipta.

Aprilia, Kharisma. (2014). Tips dan Trik Pintar Matematika. Surabaya: Cahaya Agency.

Darjiani, Yuni. (2015). “Analisis Kesulitan-kesulitan Belajar Matematika Siswa Kelas V dalam Implementasi Kurikulum 2013 di SD Piloting Se-Kabupaten Gianyar Tahun Pelajaran 2014/2015". Diakses dari https://ejournal.undiksha.ac.id/index.php/JJPGSD/article/download/5070/3826 (Diakses 2 Maret 2019).

Desmita. (2014). Psikologi Perkembangan Peserta Didik. Bandung: Remaja Rosdakarya.

Djamarah, S. B. (2008). Psikologi Belajar. Jakarta: PT. Rineka Cipta.

Heruman. (2014). Model Pembelajaran Matematika di Sekolah Dasar. Bandung: Remaja Rosdakarya.

Ismail. (2016). Diagnosis Kesulitan Belajar Siswa dalam Pembelajaran Aktif di Sekolah. Diakses dari https://jurnal.ar-raniry.ac.id/index.php/cobaBK/article/view/689/ 549 (Diakses 2 Maret 2019)

Jamaris, Martini. (2009). Kesulitan Belajar Perspektif, Assessmen dan Penanggulangannya. Jakarta : Yayasan Penamas Murni.

Kartono, Kartini. (2007). Psikologi Anak. Bandung: Mandar Maju.

Moleong. Lexy J. (2012). Metodologi Penelitian Kualitatif. Bandung: Remaja Rosdakarya. 
Nazir, Moh. (2009). Metode Penelitian. Bandung: Grahila Indonesia.

Nurtika, Triyani. (2015). "Pembelajaran Matematika Realistik untuk Meningkatkan Prestasi Belajar Sub Pokok Bahasan Perbandingan dan Skala pada Siswa Kelas V SDN Majir Kecamatan Kutoarjo". Diakses dari https://eprints.uny.ac.id/16558/1/TRYANI\%20NUTIKA_\%2007108248142.pdf (Diakses 2 Maret 2019).

Siregar, Eveline \& Hartini Nara. (2014). Teori Belajar dan Pembelajaran. Bogor : Ghalia Indonesia.

Sugiyono. (2011). Metode Penelitian Kuantitatif, Kualitatif, dan R\&D. Bandung: Alfabeta.

Suhartin. (2012). Mengatasi Kesulitan-kesulitan dalam Pendidikan Anak. Jakarta: Penerbit Libri.

Suryabrata, S. (2010). Psikologi Pendidikan. Jakarta: Rajagrafindo Persada.

Susanto, A. (2013). Teori Belajar \& Pembelajaran di Sekolah Dasar. Jakarta: Prenadamedia Group.

Syah, Muhibbin. (2018). Psikologi Pendidikan. Bandung: Remaja Rosdakarya.

Taufik, M. (2014). Psikologi Pendidikan dan Bimpesdik. Jakarta: PGSD Press.

Uno, Hamzah B. (2010). Orientasi Baru dalam Psikologi Pembelajaran. Jakarta: Bumi Aksara. 